\title{
SISTEM EKONOMI ISLAM \\ (Studi Atas Pemikiran Imam al-Ghazali)
}

\author{
Yusno Abdullah Otta
}

\begin{abstract}
Abstrak
Tulisan ini mendiskusikan pemikiran ekonomi Imam al-Ghazali yang lebih dikenal sebagai Sufi, filosof, ahli Kalam. Meskipun tidak secara rinci menjelaskan sistem ekonomi secara lugas, namun pandangan ekonomi al-Ghazali dapat dijadikan dasar dan prinsip dalam mengembangkan teori-teori ekonomi Islam. Penjelasan al-Ghazali tentang ekonomi memberikan prediksi perkembangan ekonomi dunia pada era berikutnya. Al-Ghazali telah meletakkan dasar-dasar dan landasan yang baku dan fundamental dari masalah ekonomi dan permasalahannya dengan tetap merujuk kepada dua warisan dari Rasulullah saw. Meskipun, permasalahan ekonomi pada masa itu belum sekompleks masa sekarang.

Para sarjana Muslim, khususnya al-Ghazali yang dipandang sebagai tokoh tasawuf, sebelum abad ke-15 telah menyajikan dan memprediksi perkembangan ekonomi dunia pada era berikutnya. Ini terlihat dari pemikiran mereka yang telah meletakkan dasar-dasar dan landasan yang baku dan fundamental dari masalah ekonomi dan permasalahannya dengan merujuk kepada dua warisan dari Rasulullah. Walaupun pada masa itu, permasalahan dan masalah ekonomi belum sekompleks sekarang ini. Hanya sedikit pemikir Muslim generasi berikutnya yang mengembangkan pemikiran ekonomi al-Ghazali tersebut. Para pemikir tersebut, di antaranya Ibn Khaldun dan Ibn Taimiyyah. Sementara pemikir Barat yang melakukan hal itu adalah Leonard Lessius yang mengembangkan sedikit variabel-variabel penting yang belum disentuh oleh al-Ghazali, seperti biaya produksi, resiko kerusakan barang dalam pengiriman, dan beberapa masalah transportasi yang menjadi penghambat.
\end{abstract}

Key words: ekonomi, al-Ghazali, ekonomi Islam.

\section{Pendahuluan}

Sebagai seorang hujjah al-Islam, al-Ghazali lebih dikenal dan terkenal dengan pemikiran filsafat dan tasawuf. Akan tetapi, bila dicermati dengan baik, ternyata, al-Ghazali juga memiliki gagasan pemikiran ekonomi yang dituangkannya dalam beberapa tulisannya, diantaranya dalam Ihya 'Ulum al-Din. Salah satu alasan mengapa al-Ghazali menyediakan beberapa lembar halaman dalam Ihya untuk membicarakan topik ini, karena setiap manusia hampir pasti akan bersentuhan, baik langsung maupun tidak, dengan kegiatan dan masalah ekonomi.

Sasaran utama dari diturunkannya Shari'ah Islam kepada umat Islam adalah untuk mempromosikan kesejahteraan dan kebahagian manusia yang tertuang dan terdapat dalam bentuk perlindungan keimanan, kehidupan, pemikiran dan keturunan mereka, serta kesejahteraan mereka. Kesejahteraan baru dapat dinikmati apabila 
seseorang merasa terpenuhi semua kebutuhan primer-nya, sebagai kebutuhan dasar setiap manusia. terlebih lagi bila kebutuhan yang bersifat luxurious juga terpenuhi. ${ }^{1}$ Kondisi tersebut memungkinkan terlaksana selama pereknomian yang sedang berjalan memenuhi standar yang baik, sehingga semua distribusi dalam memenuhi supply and demand tidak mengalami kendala yang berarti.

Islam, sebelum adanya sistem-sistem ekonomi Sosialis dan Kapitalis, telah memberikan landasan fundamental dan petunjuk yang dapat membawa kepada kebahagiaan manusia dalam soal materi dan ekonomi sejak seribu tahun lalu. Bahkan, Islam memuat kebaikan yang terdapat pada sistem ekonomi manapun, baik sistem dulu maupun yang akan akan datang, dan ia (sistem Islam) selalu terhindar dari keburukan. Salah satu prinsip yang ditanamkan oleh Islam, seperti yang terdapat dalam Al-Qur'ān, adalah model berdagang yang baik dan berkah; bahwa jual-beli itu harus didasarkan pada sikap rela dan tidak ada paksaan. Demikian pula dengan beberapa pesan Nabi Saw. yang terekam dalam hadisnya; bagaimana suatu system ekonomi itu dibangun dan dilaksanakan.

Masalah ekonomi selalu menarik perhatian terlebih kalangan pelaku pasar maupun akademisi serta kelompok masyarakat umum. Berbagai pemikiran telah dikeluarkan dalam rangka mencari solusi masalah ekonomi tersebut. Tetapi untuk mencari penyelesaian yang akurat dan tepat dalam mengatasi masalah ini secara keseluruhan banyak menemui kegagalan dan sangat sedikit keberhasilan yang diperoleh.

Tulisan ini mencoba mendiskusikan pemikiran al-Ghazali mengenai sistem ekonomi Islam dalam kitabnya Ihya 'Ulum al-Din, sambil berdialog dengan kedua sistem ekonomi yang ada, Sosialis dan Kapitalis. Sekaligus membantah teori dan pendapat Schumpeter yang mengatakan bahwa pembahasan mengenai sistem ekonomi Islam, khususnya mengenai mekanisme harga, sedikit sekali pembahasannya sebelum abad ke-18. ${ }^{2}$ Padahal, jauh sebelum itu topik-topik tersebut telah didiskusikan oleh para sarjana Muslim dalam karya-karya mereka, pada abad ke-11 M sampai abad ke-14 M.

1 Al-Ghazali, cf. Muhammad Umer Chapra, Islamic Economic Challange, Riyadh: International Islamic Publishing House (IIPH), 1413 H/1992 M, h. 1.

2 J.A. Schumpeter, History of Economic Analysis, London: Geroge Allen \& Unwin, 1972, h. 305. 


\section{Kegiatan Ekonomi adalah Suatu Kewajiban}

Al-Ghazali melatarbelakangi pembahasannya tentang ekonomi berdasar pada firman Allah Swt., 'Dan Kami telah jadikan siang hari sebagai waktu untuk mencari segala kebutuhan hidup', (Q.S. 78: 11), juga 'Dia telah menjadikan di bumi ini sebagai sumber daya alam yang sangat memadai untuk segala keperluan manusia, agar manusia mau bersyukur kepada Allah, tetapi sangat sedikit yang bersyukur' (Q.S. 2: 198).

Kedua perintah Allah Swt. tersebut di atas, serta perintah-perintah yang senada dalam ayat lain, mengindikasikan bahwa tindakan ekonomi bukanlah sesuatu yang melanggar hokum; bahkan merupakan bagian dari kewajiban. Allah Swt. memerintahkan kita untuk berjalan di muka bumi dalam rangka mencari sebagian karunia-Nya (Q.S. 73: 20), serta hendaklah kalian bertebaran di bumi dan carilah karunia yang dilimpahkan kepadamu (Q.S.62:10). Serta, Allah Swt. telah menjadikan bumi sebagai tempat bernaung dan menjadikan apa-apa yang di dalamnya semua untuk keperluan manusia.

Rasulullah Saw. sendiri dalam beberapa hadis mewajibkan kita untuk melakukan kegiatan ekonomi, di antaranya, 'Seorang pedagang yang jujur akan dikumpulkan di hari kiamat bersama para Shadiqin dan Syuhada'. ${ }^{3}$ Bahkan, Nabi Saw. sendiri adalah seorang pedagang yang ulung dan jujur, dengan membawa barang dagangan Khadijah dari Mekkah ke Syam.

Pandangan Al-Qur'ān terhadap harta dan kegiatan ekonomi, berangkat dari naluri manusia, bahwa manusia, secara naluriah memiliki kecintaan kepada lawan jenisnya, anak-anak, serta harta yang banyak, berupa emas, perak, kuda piaraan, binatang ternak, sawah, dan ladang (Q.S. 3: 14). 'Harta yang banyak' dalam terminology Al-Qur'ān disebut 'khair' (Q.S. 2: 180), yang arti harfiahnya adalah 'kebaikan'. Ini bukan saja berarti bahwa kekayaan adalah sesuatu yang dinilai baik, tetapi juga untuk mengisyaratkan bahwa cara dan jalan untuk memperolehnya serta bagaimana penggunaannya harus baik pula. Secara tegas Al-Qur'ān menyatakan

${ }^{3}$ H.R. Tirmidzi dan al-Hakim meriwayatkan juga dari Abi Sa'id. Menurut Tirmidzi hadis ini adalah hadis hasan, tetapi al-Hakim mengatakan hadis ini termasuk dalam katagori hadis mursal yang hasan, Ibnu Majah dan al-Hakim meriwayatkan hadis yang sama dari Ibnu 'Umar. Lihat al-Ghazali, Ihya 'Ulum al-Din, Jilid II, Beirut: Dar al-Kutb al-'Ilmiyah, t.th., h. 70. 
bahwa tanpa memperhatikan hal-hal tersebut manusia akan mengalami kesengsaraan dalam hidupnya ${ }^{4}$ meskipun kehidupannya dilimpahi dengan banyak harta.

Harta yang telah dianugerahkan Tuhan adalah untuk memenuhi semua kebutuhan manusia. Allah memerintahkan kepada manusia, terutama kaum Muslim, untuk selalu berusaha mengkonsumsi makanan yang halal lagi bergizi yang tersebar di muka bumi ini (Q.S. 2: 168). Konsekuensi logis dari larangan dan peringatan tersebut adalah, kaum Muslim diperintahkan untuk bersikap hati-hati dalam melakukan kegiatan ekonomi agar tidak terjerumus pada suatu perkara yang bernuansa syubhat, apalagi haram.

Tuhan memang telah menjadikan bumi sebagai tempat tinggal manusia dan telah menyediakan semua kebutuhan manusia di dalamnya. Akan tetapi, semua itu akan diminta pertanggungjawabannya di hadapan Tuhan sebagai 'Pemberi Amanah'. Karena itu, Tuhan senantiasa mengingatkan manusia, bahwa tempat kembalinya manusia bukan dalam kuburan, melainkan tempat kembalinya hanyalah kepada Allah (Q.S. 67: 15) untuk mempertanggungjawabkan segala kegiatan ekonomi untuk memenuhi kebutuhan hidup kita.

\section{Ekonomi Islam sebagai Ilmu dan Sistem}

Orang yang akan melakukan kegiatan ekonomi oleh al-Ghazali diharuskan untuk memiliki ilmu dan pengetahuan mengenai praktek kegiatan ekonomi, karena, kalau suatu urusan diserahkan kepada orang yang bukan ahlinya, maka tunggulah kehancurannya (hadis). Seseorang yang melakukan kegiatan ekonomi tanpa memiliki ilmu, dan berargumen, bahwa kegiatan ekonomi bukan teorinya (ilmu), tapi prakteknya, maka, dia, hampir dipastikan, dalam perjalanan kegiatan eknominya akan berhadapan dengan berbagai kesulitan, terutama ketika akan melakukan transaksi dalam skala besar, karena dia bisa tertipu. ${ }^{5}$

Para pakar dari berbagai disiplin ilmu, terutama para ahli ekonomi berbeda persepsi mengenai bangunan ekonomi Islam. Ada yang menganggap bahwa, ekonomi Islam sebagai suatu 'sistem', dan ada pula yang menganggapnya sebagai suatu yang khas yang dapat didudukan sebagai 'ilmu'. 'Sistem' dalam terminologinya dapat diartikan sebagai 'keseluruhan yang kompleks: suatu susunan hal atau sebagai yang saling berhubungan'. sementara 'ilmu adalah pengetahuan

\footnotetext{
${ }^{4}$ Quraish Shihab, Wawasan Al-Qur'an: Tafsir Maudhu'i Atas Pelbagai Persoalan Umat, Bandung: Mizan, 1996, h. 405.

${ }^{5}$ Al-Ghazali, Ihya, h. 71.
} 
yang dirumuskan secara sistematis'. ${ }^{6}$ Sehingga, secara sepintas, antara ilmu dan system memiliki perbedaan dan fungsinya masing-masing. Bila yang kedua meliputi hamper seluruh rancang bangun suatu tatanan, maka yang pertama lebih simple dan sederhana.

Sejalan dengan definisi tentang 'sistem' ini, dapat dikatakan bahwa ekonomi Islam sebenarnya merupakan bagian dari suatu tatanan kehidupan yang lengkap dan berdasarkan pada empat bagian yang jelas dari pengetahuan, yaitu, pengetahuan yang diwahyukan (Al-Qur'ān), praktek dan Sunnah yang berlaku dalam masyarakat Muslim seperti yang dicontohkan oleh Rasulullah Saw., dan ucapan-ucapan yang ber-nash, deduksi analogi, interpretasi yang datang kemudian dan konsensus yang disepekati oleh para ulama dalam suatu masyarakat yang dikenal dengan ijma'. 'Sistem' ini memuat suatu mekanisme yang built in untuk pemikiran jernih yang di sebut ijtihad. Umat Islam memahami ijtihad dengan 'upaya sungguh-sungguh dan bertanggungjawab dalam mencari solusi dari setiap permasalahan social, budaya dan politik yang berhubungan, baik secara langsung maupun tidak, dengan tradisi dan ajaran keagamaan. $^{7}$

Bila ekonomi Islam dipandang sebagai bagian dari ilmu, maka ia tidak bisa diposisikan sebagai suatu kebenaran yang absolut, dan, konsekuensinya, ia bukan pula menjadi sesuatu yang abadi. Karena itu, ilmu ini mempunyai kemungkinan untuk mengalami perobahan dari waktu ke waktu. Demikian pula dengan ilmu ekonomi Islam yang senantiasa memerlukan perobahan dan perkembangan sejalan dengan perobahan dan perkembangan zaman dan situasi. Pandangan senada juga pernah dilontarkan oleh John S. Cambs, seorang pakar ekonomi Amerika, yang mengatakan, ekonomi bukanlah ilmu melainkan sekedar harapan ilmu. ${ }^{8}$

Wilayah kajian dari ilmu ekonomi adalah memantau dan menjalankan fungsinya pada pembahasan tentang kualitas produksi dan distribusi serta bagaimana menentukan dan memperbaiki sarana-sarana kedua bagian tersebut. Hal ini bersifat universal dan berlaku bagi semua bangsa dan tidak didasarkan pada suatu ideologi

${ }^{6}$ The Oxford Pocket English Dictionary, London: Oxfodr University Press, t.th., dalam M.A. Mannan, Islamic Economy; Theory and Practice, t.tp., House and Stoughton, Ltd., t.th., h. 14.

${ }^{7}$ M.A. Mannan, Islamic Economy, h. 16.

${ }^{8}$ Yusuf Qardhawi, Daur al-Qiyam wa al-Akhlaq fi al-Iqtishad al-Islamiy, Terj. Zainal Arifin dan Dahlia Husin, Surabaya: Gema Insani Press, 1997, h. 22. 
tertentu. Karena itu, ilmu ekonomi berperan sebagai sains, yang dapat berlaku dan dipergunakan oleh semua masyarakat dari berbagai bangsa. ${ }^{9}$

Sistem ekonomi dalam pandangan ideologi Kapitalis adalah ekonomi yang hanya terbatas pada pembahasan mengenai segala sesuatu yang menjadi kebutuhan (needs) manusia dengan alat-alat (goods) pemuasnya. Sehingga bila dikaji lagi pandangan mereka hanya menyangkut aspek yang bersifat material dari kehidupan manusia. ${ }^{10}$ Sementara wilayah dan dimensi spiritualitas tidak menjadi wilayah yang diperhatikan oleh ideology kapitalis.

\section{Etika Bisnis}

Pelaku bisnis dan kegiatan ekonomi, menurut al-Ghazali, keduanya harus memiliki beberapa landasan dan kode etik. Pertama, pelaku bisnis harus memiliki niat dan tekad yang baik dalam memulai bisnisnya. Kedua, memfokuskan usaha bisnisnya kepada kewajiban-kewajiban lain yang mendukung usaha bisnisnya. Ketiga, jangan sampai kegiatan bisnisnya menomorduakan kewajibannya dalam ibadah mengingat Allah Swt., artinya meninggalkan kebahagiaan akhirat dengan mendahulukan kebahagiaan dunia. Keempat, pelaku bisnis hendaknya jangan hanya menjauhi yang haram saja, tapi juga sebaiknya meninggalkan perkara yang syubhat. Dalam menentukan kondisi tersebut, seyogyanya seorang pelaku bisnis tidak hanya melihat kepada fatwa-fatwa ulama, tapi juga mempertimbangkannya dengan mempergunakan akalnya. ${ }^{11}$

Keempa kriteria dan syarat yang ditekankan oleh al-Ghazali di atas memiliki relevansi yang signifikan dengan etika bisnis yang bersifat konvensional, bahkan lebih menjaga martabat dan keberkahan dari rizki yang diperoleh melalui kegiatan bisnis yang dilakukannya. Pada point keempat di atas penekanan al-Ghazali adalah para pelaku bisnis tidak saja diharuskan menghindari perkara yang haram semata, melainkan juga harus menghindari segala sesuatu yang tidak jelas derajat kehalalannya.

Al-Qur'ān juga mengisyaratkan bahwa pelaku bisnis jangan hanya membuka kemungkinan untuk memperoleh keuntungan sebanyak mungkin dipihaknya, dan tanpa memperhatikan nasib pelaku bisnis lainnya. Dalam konteks ini, Al-Qur'ān menyatakan, janganlah sebagian kamu -pelaku bisnis- memakan (mengambil) harta

${ }^{9}$ Ibid.

10 Taqyuddin al-Nabhani, al-Nidham al-Iqtishadiy fi al-Islam, Terj. Mohammad Maghfur Wachid, Surabaya: Risalah Gusti, 1996, h. 5

${ }^{11}$ al-Ghazali, Ihya, h. 72. 
kelompok lain dengan jalan yang bathil, dan (janganlah) kamu membawa (urusan harta) kamu kepada hakim supaya kamu dapat memakan (memperoleh) sebahagian dari harta orang lain itu dengan jalan berbuat dosa, padahal kamu mengetahuinya (Q.S. 2: 188). Ayat ini secara tegas menyatakan bahwa kegiatan ekonomi seyogyanya berjalan sesuai norma dan kaidah yang berlaku secara universal, sehingga akan tertutup segala kemungkinan bentuk penindasan dan eksploitasi.

Ayat Al-Qur'ān di atas juga memberikan isyarat bahwa harta benda adalah milik semua manusia secara kolektif dan Allah yang membaginya antara mereka secara adil berdasarkan kebijaksanan-Nya serta menetapkan hukum dan etika di dalamnya. Karena itu, Allah SWT telah memberikan rambu-rambu agar dalam upaya memperolehnya serta memanfaatkannya tidak menimbulkan perselisihan dan kerusakan. Redaksi ayat di atas mengisyaratkan bahwa hak dan kebenaran harus senantiasa berada di antara mereka yang tarik menarik dalam kegiatan ekonomi dan bisnis tersebut. ${ }^{12}$

Dalam kegiatan ekonomi (jual beli), yang telah dihalalkan Allah Swt. (Q.S. 2: 275), al-Ghazali memberikan tiga rukun. Pertama, pelaku bisnis; kedua, barang yang diperdagangkan; dan ketiga, lafadh transaksi atau aqad. Pelaku bisnis haruslah orang yang akil baligh atau dewasa dan merdeka; bukan anak-anak, orang gila, dan hamba (budak) atau orang buta. Rukun ini juga berlaku bagi lawan bisnisnya. Karena anak kecil, lanjut al-Ghazali, belum termasuk orang mukallaf begitu pula orang gila, sehingga transaksi keduanya dianggap batal secara hukum. Al-Ghazali mengutip pendapat al-Syafi'i, yang mengatakan bahwa perniagaan yang dilakukan oleh atau dengan anak kecil tidak sah/batal, walaupun walinya memberikan izin untuk itu, karena salah satu syarat dalam melakukan transaksi adalah berakal. Karena itu, meskipun dia berakal tetapi posisinya sebagai hamba (budak), maka kegiatan ekonominya, baik jual-beli atau transaksinya, tidak sah atau batal demi hukum, terkecuali setelah mendapat persetujuan dari tuannya. Izin yang diberikan tuannya tersebut, menurut al-Ghazali, juga harus didengar dan diketahui secara umum, bila tidak, maka kegiatan ekonominya tetap dianggap tidak sah/batal. Dan bagi seorang buta, karena dia tidak bisa melihat dalam jual beli, maka, diharuskan mewakilkan kepada orang yang dipercaya olehnya.

\footnotetext{
${ }^{12}$ Bandingkan dengan firman Allah dalam Q.S. 59 : 7...Agar jangan sampai harta/kekayaan itu hanya berputar pada satu kelompok (para konglomerat) saja...
} 
Al-Ghazali menambahkan, bahwa kegiatan ekonomi dan transaksi yang dilakukan dengan orang kafir adalah boleh, kecuali dalam jual beli Mushhaf, dan peralatan perang, bila dia (orang kafir) seorang tentara, serta barang yang diharamkan ajaran Islam, dan bila ketiga macam transaksi ini tetap dilakukan, maka hal itu tertolak. Karena itu, dapat merugikan kaum Muslim secara general.

Rukun yang kedua, adalah barang yang diperdagangkan. Al-Ghazali memberikan 6 (enam) syarat dalam masalah ini, yaitu, hendaknya barang tersebut bukanlah sesuatu yang najis, seperti anjing dan babi serta khamar. Kedua, barang tersebut harus bisa memberikan manfaat bagi kedua belah pihak, sehingga tidak diperbolehkan memperjualbelikan serangga, tikus, dan ular. Ketiga, hendaknya barang tersebut merupakan milik penuh oleh penjual, atau telah diberi izin untuk diperjualbelikan. Keempat, hendaknya barang tersebut sanggup diserahkan pada saat transaksi. Dalam hal Rasulullah Saw. melarang bay'u al-gharar. ${ }^{13}$

Kelima, hampir sama dengan yang keempat, di mana barang tersebut harus diketahui jenis dan sifatnya serta kadar ukurannya. Kadar barang tersebut, seperti jumlahnya, beratnya dan sifatnya harus dilihat secara 'ainiy bukan sedekar dzanniy. Keenam, barang tersebut berada di tangan penjual, dan bila syarat ini tidak dipenuhi, maka, Rasulullah Saw. melarang transaksi dengan barang yang tidak ada pada penjualnya.

Sedangkan rukun ketiga adalah adanya lafadh 'aqad dalam transaksi. Lafadz ini bisa diucapkan dengan jelas atau cukup dengan kinayah. Hal ini, sekarangpun masih relevan, walaupun ada transaksi yang hanya dilakukan melalui komputer (internet). Karena kedua belah pihak, tidak akan bisa mengadakan transaksi tanpa adanya ungkapan yang jelas maupun secara kinayah dalam transaksinya.

\section{Prinsip Keadilan dan Kebaikan}

Keadilan termasuk salah satu dari nilai-nilai dasar dan prinsip ekonomi Islam, di samping keseimbangan dalam kepemilikan. Di samping itu, prinsip ini merupakan titik tolak dan sebagai proses dari seluruh kegiatan manusia tujuan. Dalam bidang ekonomi misalnya, prinsip ini harus menjadi motor pendorong yang efisiensi dalam memperoleh keuntungan dan, juga sekaligus, destruksi pemborosan (Q.S. 17: 16). Dalam distribusi, keadilan harus bediri sebagai judgment yang akurat, faktor produksi dan kebijakan harga, yang akan bermuara pada keseimbangan yang wajar

${ }^{13}$ Jual beli dengan barang yang samar-samar seperti jual beli ikan di laut atau buah yang masih berada di pohon dan belum matang dan emas dalam tanah. 
dan kadar yang sebenarnya (Q.S. 15: 19). Begitu pula, keadilan adalah untuk mengupayakan suatu alokasi sejumlah hasil kegiatan ekonomi tertentu (kekayaan) untuk mereka yang kekurangan modal, agar mampu meningkatkan produktifitas yang dapat disalurkan melalui beberapa media seperti, zakat, infak dan sedekah.

Al-Ghazali membagi beberapa bagian dalam kegiatan ekonomi yang rentang dengan ketidakadilan. Prinsip kebaikan dan keadilan dalam kegiatan ekonomi Islam diantaranya, pertama, bagi pemilik modal dilarang menimbun barang (ihtikar) yang menjadi konsumsi bagi masyarakat umum, dengan tujuan agar harganya melambung, setelah itu dikeluarkan kepasaran. Al-Ghazali mengkategorikan perbuatan dan tindakan ini sebagai dhalim, karena mempersulit banyak orang. Al-Ghazali menyitir hadis Nabi Saw. yang mengatakan 'barang siapa yang menimbun dan menyimpan makanan selama empat puluh hari, kemudian dia bersedekah dengan hasil penjualan dari barang timbunannya tersebut, maka sedekahnya itu tidak bisa menjadi kafarat terhadap penimbunannya'. ${ }^{14}$

Prinsip di atas dimaksudkan, agar kekayaan itu tidak hanya berputar dan tertimbun di kalangan tertentu, orang kaya dan bermodal saja (Q.S. 59: 7). Juga, karena ihtikar adalah bagian dari sistem ekonomi Kapitalis. Lebih dari itu, model kegiatan bisnis demikian merupakan salah satu bagian dari politik ekonomi mereka ${ }^{15}$ yang profit minded tanpa memikirkan konsekuensi dari tindakannya tersebut. Nabi Saw. Mengingatkan, dalam hadis lain, bahwa 'dua orang yang melakukan kegiatan ekonomi akan diberkahi oleh Allah kegiatan ekonomi mereka selama keduanya saling jujur dan saling menasehati, tapi bila mereka saling berbohong dan menipu, maka, Allah Swt. akan mencabut keberkahan dari kegiatan ekonomi tersebut. ${ }^{16}$

Al-Ghazali membedakan antara prinsip keadilan dengan kebaikan dalam kegiatan ekonomi. Keadilan tidak berakhir pada keselamatan saja. Dan dalam kegiatan ekonomi dia hanya berputar di antara modal dan para pemegang modal saja. Tetapi kebaikan merupakan sebab dari kemenangan dan perolehan kebahagiaan. Dan dia berputar pada kegiatan ekonomi yang profit minded. Sehingga, bila seorang bisnisman yang menjadikan roda bisnisnya atas landasan Islam, dia tidak hanya mencari keuntungan duniawi semata, tapi juga dia mengejar keuntungan akhirat

\footnotetext{
${ }^{14}$ H.R. Abu Mansur dalam Musnadnya. Lihat al-Ghazali, Ihya, h. 82.

15 Yusuf Kamal, Al-Islam Wa al-Madzahib al-Iqtishadiyah al-Mu'ashirah, t.tp., Dar alWafa', 1414 H / 1990 M, h. 34; bandingkan dengan M. Nejatullah Siddiqi, Muslim Economic Of Contemporary Literature, Leiden: The Islamic Foundation, 1408 H/1988 M, h. 10 - 11

${ }^{16}$ H.R. Muttafaqun 'alaihi dari Ibnu Hazam. Lihat al-Ghazali, Ihya, h. 86.
} 
dengan cara menjalankan bisnisnya dalam bingkai sistem Islam dan menjauhi kezaliman. Rasulullah Saw. bersabda, "Allah Swt menyayangi seseorang yang mempermudah dalam berdagang dan mempemudah dalam membeli.",17

Ciri khas nilai keadilan di atas adalah bahwa kegiatan ekonomi masyarakat (baca: umat Islam) harus berorientasi kepada kemakmuran dan berdasarkan prinsip keadilan, sehingga tercapai tujuan makmur dalam keadilan dan adil dalam kemakmuran, dan ungkapan itu bukan sekedar slogan saja. Bila terjadi dokontruksi pada nilai keadilan ini, akan berdampak pada distorsi masyarakat yang bersangkutan.

Walaupun Barat mengklaim dan mengakui bahwa mereka berbisnis berdasarkan persaingan pasar bebas, dengan memperhatikan pemerataan kepemilikan modal dan menolak sistem ekonomi Sosialis, namun, kenyataannya terjadi praktek eliminasi pesaingnya. Masing-masing ingin memonopoli bisnis. Dan Islam sangat menentang praktek monopoli, apapun bentuknya, karena sangat merugikan konsumen $^{18}$ serta tidak sesuai dengan asas keadilan dan kebaikan.

\section{Pasar Bebas}

Berbicara mengenai pasar, dalam setiap sistem ekonomi seperti Kapitalis, Sosialis, dan Islam, tidak akan lepas dari permasalahan harga bagi setiap barang produksi yang dipasarkan dalam suatu pasar. Keterkaitan ini terjadi, karena, keduanya, pasar dan harga, merupakan satu mekanisme yang tidak bisa lepas dan berdiri serta berjalan sendiri. Sebab harga suatu produksi bisa ditentukan oleh situasi dan mekanisme pasar dan begitu pula sebaliknya.

Roda kegiatan ekonomi, dalam sistem ekonomi manapun, pasar adalah tempat yang signifikan. Di sini sirkulasi keuangan bergerak dan sejumlah transaksi dilakukan. Al-Ghazali telah memberikan dasar dari mekanisme pasar, di antaranya, perdagangan, al-riba, salam, Qiradh, Syirkah, teori harga. Riba adalah model pasar yang dipraktekan oleh orang-orang Yahudi sebelum dan sesudah kedatangan Islam. Cara mereka mengeksploitasi pihak kedua, sehingga merugikan lawan bisninya, maka, praktek ini dilarang dan diharamkan Allah dan Rasul-Nya ${ }^{19}$ (Q.S. 2: 275 279).

\footnotetext{
${ }^{17}$ al-Ghazali, Ihya, h. 87.

${ }^{18}$ Choirul Fuad Yusuf, Etika Bisnis Islam: Sebuah Perspektif Lingkungan Global, dalam 'Ulum Al-Qur'an, h. 20. Bandingkan pula dengan M. Nejatullah Siddiqi, "Monopoly and Monopolistic Competetion", dalam Sayyid Tahir, et. all (eds.), Readings in Microeconomis: An Islamic Perspective, Malaysia: Longman, 1990, h. 165 - 175.

${ }^{19}$ H.R. Ahmad dan Muslim dari Jabir. Lihat, Shahih Jami’ al-Shaghir, no. 5090.
} 
Menurut teori kompetisi sempurna yang lama, pasar adalah berkumpulnya sejumlah produsen dan konsumen yang sulit untuk menentukan jumlah pemainnya. Di dalamnya terjadi sirkulasi dan transaksi yang bebas, seperti kebebasan untuk memilih teknologi dan metode produksi serta cara memasarkannya. Kebebasan memperoleh informasi tentang suatu produksi yang dilegitimasi oleh pemerintah, ${ }^{20}$ serta kebebasan lainnya yang tidak bertentangan dengan nilai dan prinsip ekonomi Islam.

Di sejumlah pasar, teknik yang dipergunakan dalam memasarkan produksi bisa menjadikan pasar tersebut survive, di samping terpenuhinya pendapatan yang memadai bagi para pekerjanya. Setiap faktor pemasaran barang disesuaikan dengan biaya produksi. Harga ditentukan oleh mekanisme pasar dan kekuatan pasar serta dipatokan serendah mungkin agar dapat dijangkau oleh semua konsumen. Inilah bentuk mekanisme pasar yang dipraktekan dalam sistem ekonomi Islam. Harga yang berlaku di dalam pasar ditentukan dan mengacu pada kekuatan kebebasan pasar dan tidak diintervensi oleh siapapun, baik pemilik modal maupun pelaku bisnis, apalagi pemerintah. Dalam ungkapan lain, harga adalah bebas, dan berjalan sesuai dengan pasar yang berlaku.

Kegiatan ekonomi, dalam mekanisme pasar, yang bebas dari intervensi pihak luar, merupakan pilar utama dan pertama dari mekanisme pasar Islam. Kebebasan ini didasarkan pada ajaran Islam yang fundamental. Al-Qur'ān banyak memerintahkan dan mengingatkan umat Islam secara umum dan secara khusus kepada para pelaku bisnis untuk bertanggung jawab atas semua tindakan, karena Allah Swt. Tidak pernah luput dalam mengawasi sehingga setiap tindakan pasti diketahuinya (Q.S. 3: 128 dan Q.S. 5: 5). Rasa tanggung jawab itu membuat setiap Muslim memiliki sense of freedom dalam menentukan pola dan perilaku hidup dalam berbagai bidang kehidupan baik politik, ekonomi, dan sosial serta pendidikan, bahkan dalam agama.

Sepanjang sejarah masyarakat Muslim, kebebasan ekonomi telah berjalan dan dipraktekkan sebagai suatu sistem yang resmi. Rasulullah Saw. menolak untuk menentukan harga yang beredar dalam pasar walaupun harga suatu barang melambung. Penolakan ini didasarkan pada prinsip kebebasan yang ada dalam bisnis. Dan tidak memanfaatkan kekuatan dan sekaligus kekuasaan para pemilik modal

${ }^{20}$ Paul A. Samuelson, Economics, (London: McGraw-Hill International Book Co., 1980). Bandingkan dengan Monzer Kahf, "Market Structure: Free Co-Operation", dalam Sayyid Tahir et.all (eds.) Readings in Microeconomis, h. 146. 
untuk menjual barang produksi mereka lebih rendah dari harga pasar, sehingga bisa menggoyang harga. Tetapi perobahan harga disebabkan oleh faktor supply dan demand konsumen akan barang tersebut, dan bukan pula oleh kekuatan pemerintah yang berkuasa. $^{21}$

Nabi Saw. sangat keras untuk meminimalkan perbedaan informasi mengenai harga dalam pasar. Ketika dia (Nabi Saw.) menolak keras penjualan hasil bumi sebelum sampai ke pasar; suatu tindakan yang telah menjadi kebiasaan orang Yahudi, dengan tujuan dibeli dengan harga murah, kemudian dijual dua kali lipat dari harga sebelumnya dipasaran. ${ }^{22}$ Nabi Saw. juga menolak praktek penipuan dan monopoli, sampai-sampai menyamakan mereka dengan orang berdosa besar dan telah keluar dari Islam. ${ }^{23}$

\section{Penutup}

Para sarjana Muslim, khususnya al-Ghazali yang dipandang sebagai tokoh tasawuf, sebelum abad ke-15 telah menyajikan dan memprediksi perkembangan ekonomi dunia pada era berikutnya. Ini terlihat dari pemikiran mereka yang telah meletakkan dasar-dasar dan landasan yang baku dan fundamental dari masalah ekonomi dan permasalahannya dengan merujuk kepada dua warisan dari Rasulullah. Walaupun pada masa itu, permasalahan dan masalah ekonomi belum sekompleks sekarang ini.

Hanya Leonard Lessius yang mengembangkan sedikit variabel-variabel penting yang belum disentuh oleh al-Ghazali, Ibnu Taimiyyah dan Ibnu Khaldun, seperti biaya produksi, resiko kerusakan barang dalam pengiriman, dan beberapa masalah transportasi yang menjadi penghambat. ${ }^{24}$

\footnotetext{
${ }^{21}$ Ahmad Ibn Taimiyyah, Al-Hisbah fi al-Islam, Beirut: Dar al-Kutb 'Arabiyah,1976, h.25.

${ }^{22}$ Ibid.

${ }^{23}$ Ali 'Abdu al-Rasul, al-Mabadi al-Iqtishidiyyah fi al-Islam, (Kairo: Dar al-Fikr al-'Arabi, 1968), h. 16-18.

${ }^{24}$ A.A. Islahi, 'Economics Views of Ibn Taimiyyah', Ph.D. Thesis, Aligarh Muslim University; dalam Sayyid Tahir, et. All (eds.), op.cit., h. 163.
} 


\section{Daftar Pustaka}

Al-Ghazali, Ihya 'Ulum al-Din, Jilid II, Beirut: Dar al-Kutb al-'Ilmiyah, t.th.

Chapra, Muhammad Umer, Islamic Economic Challange, Riyadh: International Islamic Publishing House (IIPH), 1413 H/1992 M.

Islahi, A.A., 'Economics Views of Ibn Taimiyyah', Ph.D. Thesis, Aligarh Muslim University; dalam Sayyid Tahir, et. All (eds.), Readings in Microeconomis: An Islamic Perspective, Malaysia: Longman, 1990.

Kahf, Monzer "Market Structure: Free Co-Operation", dalam Sayyid Tahir et.all (eds.) Readings in Microeconomis: An Islamic Perspective, Malaysia: Longman, 1990.

Kamal, Yusuf, Al-Islam Wa al-Madzahib al-Iqtishadiyah al-Mu'ashirah, (t.tp., Dar al-Wafa', $1414 \mathrm{H}$ /1990 M).

M.A. Mannan, Islamic Economy; Theory and Practice, t.tp., House and Stoughton, Ltd., t.th.

Nabhani, Taqyuddin al-, al-Nidham al-Iqtishadiy fi al-Islam, Terj. Mohammad Maghfur Wachid, Surabaya: Risalah Gusti, 1996.

Rasul, Ali ‘Abdu al-, al-Mabadi al-Iqtishidiyyah fi al-Islam, (Kairo: Dar al-Fikr al-‘Arabi, 1968).

Samuelson, Paul A., Economics, (London: McGraw-Hill International Book Co., 1980.

Schumpeter, J.A., History of Economic Analysis, London: Geroge Allen \& Unwin, 197.

Shihab, Quraish, Wawasan Al-Qur'an: Tafsir Maudhu’i Atas Pelbagai Persoalan Umat, Bandung: Mizan, 1996.

Siddiqi, M. Nejatullah, Muslim Economic Of Contemporary Literature, (Leiden: The Islamic Foundation, 1408 H/1988 M).

Tahir, Sayyid, et. all (eds.), Readings in Microeconomis: An Islamic Perspective, Malaysia: Longman, 1990.

Taimiyyah, Ahmad Ibn, Al-Hisbah fi al-Islam, Beirut: Dar al-Kutb ‘Arabiyah,1976.

Tim Penulis, The Oxford Pocket English Dictionary, London: Oxfodr University Press, t.th.

Yusuf Qardhawi, Daur al-Qiyam wa al-Akhlaq fi al-Iqtishad al-Islamiy, Terj. Zainal Arifin dan Dahlia Husin, Surabaya: Gema Insani Press, 1997. 